\title{
Ewangelizacja w duchu independentyzmu katalońskiego
}

\author{
Wioletta Husar-Poliszuk (iD https://orcid.org/0000-0001-9891-3227 \\ Instytut Nauk o Polityce i Administracji \\ Uniwersytet Zielonogórski \\ e-mail: w.husar@ip.uz.zgora.pl
}

\section{Abstract \\ Evangelisation in the Spirit of Catalan Independence}

This article presents Catalan independentism as a political religion. The main area of interest is the process of evangelisation to ensure the effectiveness of contemporary thought and the independence movement in Catalonia. The aim of the analysis is to verify the instruments and mechanisms through which an effective and permanent evangelization in the spirit of independentism is possible.

Keywords: Catalan independentism, Catalan nationalism, Catalan independence, political religion, evangelization

Słowa kluczowe: independentyzm kataloński, nacjonalizm kataloński, niepodległość Katalonii, religia polityczna, ewangelizacja

\section{Wprowadzenie}

Konflikt na linii Hiszpania-Katalonia od kilku lat cieszy się dużym zainteresowaniem badaczy i stanowi przedmiot licznych analiz o charakterze interdyscyplinarnym. W tym kontekście wyjątkowo interesujące wydaje się ujęcie kwestii niepodległości Katalonii przez pryzmat politologii religii. Związki independentyzmu katalońskiego z religią mogą pozornie wydawać się mało znaczące, jednak po głębszej analizie ujawnia się ich duży wpływ na stosunki społeczno-polityczne w regionie i całej Hiszpanii.

Celem artykułu jest analiza mechanizmów i narzędzi (podmiotów), za pomocą których może dochodzić do procesu permanentnej ewangelizacji czy nawet 
indoktrynacji w celu postrzegania independentyzmu jako jedynej drogi do wypełnienia mesjańskiej misji - utworzenia niepodległego państwa. Jednocześnie independentyzm mógłby zyskać w ten sposób charakter swoistej religii politycznej. Prowadzone badania są podyktowane poszukiwaniem odpowiedzi na następujące pytania badawcze: Jaka jest istota independentyzmu katalońskiego? Jakie atrybuty religii wykorzystują independentyści? W jaki sposób przebiega proces ewangelizacji i dlaczego ma on znaczenie? Podczas eksplikacji szczególnie użyteczne były analiza instytucjonalno-prawna oraz analiza danych zastanych, a także metody historyczna i komparatystyczna.

\section{Istota independentyzmu katalońskiego}

Pojęcie independentyzm wskazuje na powiązania z językiem łacińskim: termin „independens” rozumiany jest jako „niezależny”, „samodzielny”, „niepodległy”. W prowadzonej analizie independentyzm oznacza działania mające na celu uzyskanie niepodległości regionu/państwa. W związku z tym independentyzm kataloński to z jednej strony myśl polityczna, w ramach której wysuwane jest żądanie utworzenia niepodległego państwa katalońskiego, a z drugiej - ruch społeczno-polityczny, który ukonstytuował się w Katalonii w odpowiedzi na prace związane z projektem nowego statutu autonomii. W aspekcie myśli politycznej independentyzm stanowi poziom „fundamentalny”, natomiast na poziomie „operacyjnym” przyjmuje postać ruchu społeczno-politycznego, w obrębie którego funkcjonują: aktorzy i podmioty polityczne, organizacje i jednostki niezrzeszone ${ }^{1}$.

Początki katalonizmu, a tym samym independentyzmu, sięgają zarania XIX wie$\mathrm{ku}$ : prowincjonalizmu i odrodzenia kulturowego. Funkcjonował on wówczas niemal wyłącznie jako ruch kulturalny aż do lat 60 ., następnie doszło do jego polityzacji. Na kształt nacjonalizmu katalońskiego, a później independentyzmu wpłynęło wiele czynników. Poza nurtami i światopoglądami o zasięgu globalnym, jak na przykład marksizm, znaczącą rolę odegrały rodzime poglądy, w tym: federalizm Francisca Pi y Margalli czy federalizm i regionalizm, który reprezentował Valentí Almirall i Llozer, tradycjonalizm katolicki José Torrasa y Bagesa, a także założenia katalonizmu Enrica Prata de la Riby, gdzie uznał Katalończyków za naród, czy lewicowe poglądy Antonia Rovira y Virgili dotyczące świadomości i własnej woli Katalończyków, a w późniejszym okresie myśl nacjonalistyczna Jordi Pujola i Soleya. W 1901 roku powstała pierwsza katalońska partia nacjonalistyczna Lliga Regionalista, w 1914 roku zaś scalono cztery prowincje katalońskie (Mancomunitat). W ten sposób od początku drogi katalonizmu i independentyzmu przeplatały się, a w wielu przypadkach były tożsame.

Idea niepodległości Katalonii pojawiła się w regionie w XIX wieku, jednak miała charakter efemeryczny. Z początkiem XX wieku sprzyjające czynniki, takie jak:

${ }^{1}$ Por. W. Husar-Poliszuk, Katalończycy. Od budowy własnej tożsamości do independentyzmu w regionie, Poznań 2020, s. 24. 
narastający konflikt społeczno-polityczny, rewolucyjne nastroje społeczne, antagonizmy katalońsko-hiszpańskie, powstanie wielkanocne w Dublinie, kryzys gospodarczy czy wzrost zainteresowania kwestią samostanowienia narodów, sprawiły, że część radykalnych katalonistów zaczęła wysuwać coraz śmielsze rewindykacje polityczne.

Wymienione komponenty pozytywnie wpłynęły na zmianę w percepcji politycznej części Katalończyków. Pozwoliło to na założenie pierwszych partii politycznych o konotacjach independentystycznych, jak na przykład Federació Democràtica Nacionalista (FDN) w 1919 roku. Ugrupowanie wykazywało tendencje separatystyczne, jednak Katalonia miała zostać niezależną składową konfederacji iberyjskiej². Ten swego rodzaju nowy katalonizm charakteryzował się większą radykalnością w poglądach, z uwzględnieniem celów separatystycznych ${ }^{3}$. Nowa trajektoria nacjonalizmu opierała się przede wszystkim na wspólnocie językowej, która miała determinować jedność narodową Katalończyków. Jednym z fundatorów partii był radykalny katalonista Francesc Macià i Llussà, który już w 1922 roku stworzył pierwszą partię independentystyczną - Estat Català, deklarującą jednoznacznie chęć odłączenia Katalonii od Hiszpanii. Członkowie Estat Català określali ją jako podmiot o orientacji separatystycznej, niedogmatycznej i międzyklasowej. Na tej podstawie wyraźnie widać, iż independentyzm kataloński ma swoje źródła w katalonizmie.

Istotne jest, że w 1931 roku F. Macià został liderem nowo powstałej Esquerra Republicana de Catalunya (ERC), jednej z najstarszych współcześnie istniejących i najbardziej wpływowych partii independentystycznych w regionie. Od początku ugrupowanie deklarowało dążenie do niepodległości regionu ${ }^{4}$. Partia cieszyła się stosunkowo dużym poparciem Katalończyków. W 1931 roku F. Macià wraz z Lluísem Companysem i Joverem ogłosili powstanie niezależnej Republiki Katalońskiej w ramach Federacji Iberyjskiej oraz powołanie katalońskiego rządu tymczasowego ${ }^{5}$. Ostatecznie na drodze zawartego $\mathrm{z}$ władzami centralnymi kompromisu utworzono autonomię katalońską i Generalitat.

Myśl independentystyczna przez kilka późniejszych dekad była obecna niemal wyłącznie na płaszczyźnie politycznej, wśród katalońskich decydentów politycznych i działaczy ${ }^{6}$. Sytuacja uległa zmianie, kiedy od początku XXI wieku idea niepodległości stopniowo zyskiwała zwolenników, w związku z tym na przełomie 2005/2006 roku zaczął kształtować się ruch independentystyczny. Bezpośrednim

${ }^{2}$ Por. E.K. Kulak, Kształtowanie się poczucia tożsamości Katalończyków na podstawie piśmiennictwa okresu odrodzenia kulturalnego i narodowego (XIX w. - początek XX w.), Kraków 2016, s. 264.

${ }^{3}$ Cele separatyzmu: 1. uworzenie lub poszerzenie autonomii; 2. identa; 3 . utworzenie własnego państwa, zob. np.: D.L. Horovitz, Patterns of ethnic separatism, „Comparative Studies in Society and History”, April 1981, t. 23, nr 2, s. 165-169; P. Dobrowolski, Separatyzm ślaski-historia i współczesność, [w:] Regionalizm a separatyzm - historia $i$ wspótczesność. Śląsk na tle innych obszarów, M.W. Wanatowicz (red.), Katowice 1995.

${ }^{4}$ Por. S. Alonso, Challenging the State: Devolution and the Battle for Partisan Credibility, Oxford 2012, s. 77.

${ }^{5}$ Por. J. Roglan, 14 d'abril: la Catalunya republicana (1931-1939), Valls 2006, s. 13.

${ }^{6}$ Zob. F. Cucurull, Panoràmica del nacionalisme català: Del 1914 al 1931, París 1975; J. Crexell i Playà, El Complot de Garraf, Montserrat 1988. 
bodźcem było odrzucenie przez Kortezy Generalne projektu statutu, który wcześniej przyjął parlament kataloński, co zapoczątkowało proces negocjacji jego zmian, ostatecznego przyjęcia w 2006 roku oraz zaskarżenia do Trybunału Konstytucyjnego Hiszpanii. Jego orzeczenie w 2010 roku stało się impulsem dla procesu radykalizacji independentyzmu $\mathrm{w}$ regionie.

Warto zaznaczyć, iż współczesny independentyzm kataloński jest zjawiskiem różnych prędkości i motywacji. Jego wewnętrzne zróżnicowanie dotyczy m.in. poglądów, w jaki sposób i za pomocą jakich metod osiągnąć niepodległość. Przykładowo znacząca część środowisk independentystycznych opowiada się za legalną drogą jej uzyskania.

\section{Religia polityczna a independentyzm}

Religia polityczna rozumiana jest $\mathrm{w}$ analizie jako szczególny związek religii i polityki, a mianowicie polityka i działania decydentów politycznych tworzą swoisty ekwiwalent religii w warunkach jej funkcjonowania ${ }^{7}$. Staje się to możliwe w sytuacji, gdy jednostki rządzące uznają, iż proponowana przez nie forma organizacji życia społecznego jest jedyną właściwą wizją przyszłości i bez względu na koszty i ewentualne konsekwencje musi zostać zrealizowana. Przy czym drugorzędne znaczenie mają tu instrumenty, jakie zostaną wykorzystane do jej urzeczywistnienia, łącznie z wykorzystaniem przemocy i terroru ${ }^{8}$ Sakralizacja polityki wiąże się ściśle z inkorporacją $\mathrm{z}$ tradycyjnej religii sfery sacrum i zespolenie jej z profanum. Do mezaliansu religii i polityki w interesującym nas kontekście dochodzi na wielu płaszczyznach. W pracy skupiono się na kwestiach dotyczących: obligatoryjnego kultu, specyficznej kosmowizji, obietnicy raju, kanonu wartości wpływających na moralność społeczną, mesjanizmu oraz stałej ewangelizacji i katechizacji. Warto doprecyzować, że, po pierwsze, pomimo iż zwłaszcza obligatoryjny kult i specyficzna kosmowizja utożsamiane są z religią chrześcijańską, to w analizie zyskują charakter „świecki”. Są one bowiem pewnym procesem formowania religii politycznej przez jej zwolenników, misyjnym nauczaniem. Po drugie, religia chrześcijańska jest wyjątkowo bliska Katalończykom, gdyż w dużym stopniu zdeterminowała ich tożsamość narodową .

Independentyzm nie ma bezpośredniego związku z transcendencją, jednak można w nim odnaleźć elementy z dorobku religii. Szczególnie ważnym komponentem jest kult narodu katalońskiego oraz niepodległej Katalonii ${ }^{10}$. Sakralizacja narodu przez independentystów oznacza czczenie samych siebie przez Katalończyków, rozpatrywanych jednak przez pryzmat wspólnoty, a nie autonomicznych jednostek. Dla jego

${ }^{7}$ Por. P. Burgoński, Modele relacji między religia i polityka, [w:] Religia i polityka. Zarys problematyki, P. Burgoński, M. Gierycz (red.), Warszawa 2014, s. 222.

${ }^{8}$ Ibidem.

${ }^{9}$ Zob. W. Husar-Poliszuk, Znaczenie czynnika religijnego w konstruowaniu katalońskiej tożsamości narodowej, Zielona Góra 2017, s. 155-164; W. Husar-Poliszuk, B. Secler, P.S. Ślusarczyk, Znaczenie katolicyzmu dla ksztaltowania się katalonizmu i independentyzmu w Katalonii, [w:] eidem, Polityka wyznaniowa. Konteksty innych polityk publicznych. Austria, Katalonia, Polska, Zielona Góra 2018, s. 81-106.

${ }^{10}$ Por. J. Barraycoa, Historias ocultadas del nacionalismo catalán, Madrid 2011, s. 57. 
dobra jednostka powinna rozróżniać dobro i zło, wyrzec się egoizmu oraz pełnić posługę dla wspólnoty narodowej - zastępując Boga Ojczyzną, narodem czy też niepodległością regionu ${ }^{11}$. Warto podkreślić, iż kult w katalonizmie i independentyzmie nie jest czymś nowym. Przejawia się od lat w koncepcjach, symbolach, rytuałach czy zaangażowaniu duchowieństwa ${ }^{12}$.

Elementem mogącym konstytuować independentyzm w kategoriach religii politycznej jest także specyficzny pogląd na rozwiązanie tzw. problemu katalońskiego. Składa się na niego zbiór przekonań opartych na wierze nacjonalistycznej i independentystycznej, która pozwala na wyjaśnienie wszystkiego, co nas otacza, a jednocześnie determinuje zachowanie. Stworzona kosmowizja przekazywana jest poprzez język, jak również poprzez krew, co daje możliwość naturalnego sposobu rozumowania. Tym samym czynnik biologiczny staje się argumentem politycznym ${ }^{13}$. Nie oznacza to jednak, że independentyzm ma charakter ekskluzywny. Przeciwnie, tworzy na tyle otwarte ramy, aby móc przyjąć wiernych definiowanych nie tylko biologicznie, ale być może, co jest ważniejsze, poprzez samoidentyfikację. Potwierdza to szeroka definicja Katalończyka stworzona przez J. Pujola: „Katalończykami są wszyscy, którzy żyją i pracują w Katalonii oraz chcą nimi być" ${ }^{14}$. Dzięki temu wspólnota katalońska może stale powiększać swój kapitał społeczny.

Dodatkowo można dostrzec wykorzystanie przez independentystów symbolu raju, ponieważ independentyzm kataloński za swój fundament uznaje palingenetyczny mit narodu. Zgodnie z nim naród ma zostać zbawiony dzięki wskrzeszeniu go przez Zbawcę, czyli w tym przypadku ruch independentystyczny ${ }^{15}$. Będzie to swoiste odrodzenie narodowe w granicach Republiki Katalońskiej. Ściśle z tym korespondują podkreślanie martyrologii narodowej oraz mitologizacja historii ${ }^{16}$.

Propagowanie wiedzy o własnym narodzie, jego tożsamości oraz elementów tworzących pentagram tożsamościowy ma na celu zjednoczenie wspólnoty, budowę głębokich więzi emocjonalnych, co ułatwia wyznaczenie wspólnych punktów odniesienia ${ }^{17}$. Przypomina to permanentną ewangelizację i katechizację, które wspierają kształtowanie się moralności społecznej Katalończyków. Mając na uwadze siłę oddziaływania swoistej ewangelizacji na jednostki i wspólnotę, wyjątkowo interesująca wydaje się identyfikacja jej mechanizmów i narzędzi.

${ }^{11}$ P. Moa, Los nacionalismos vasco y catalán: En la Guerra Civil, el franquismo y la democracia, Madrid 2013, s. 432-433.

12 Por. I. Domínguez, El alma independentista de la Iglesia catalana, „El País”, 29.09.2017, https:// elpais.com/politica/2017/09/28/actualidad/1506627882_121321.html [dostęp: 11.06.2021].

${ }_{13}$ Por. J. Vilches, El catalanismo como religión, „E1 Español”, 11.09.2018, https://www.elespanol. com/opinion/tribunas/20180911/catalanismo-religion/337086291_12.html [dostęp: 12.06.2021].

${ }_{14}$ J. Pujol, Tot compromis comporta risc, Barcelona 1997, s. 133.

${ }_{15}$ Por. J. Vilches, op. cit.

${ }^{16}$ Zob. F. Kubiaczyk, Historia, pamięć i nacjonalizm po katalońsku, „Studia Europaea Gnesnensia” 2015, nr 12.

${ }^{17}$ Por. A. Grzechynka, op. cit., s. 140-141. 


\section{Independentystyczna ewangelizacja}

Pierwotnie to nacjonalizm kataloński miał swych kaznodziejów, później zyskał ich independentyzm. Wśród panteonu ewangelistów independentyzmu ważne miejsce obok F. Macià zajmuje J. Pujol ${ }^{18}$, który przejął w swoich wystąpieniach retorykę kościelną (język, konceptualność, emocjonalność) ${ }^{19}$ i za jej pośrednictwem przedstawiał wizję wolnej Katalonii, która stała się obiektem czci. Wykorzystując schematy teologiczne, przekonywał Katalończyków, aby nie tracili wiary w Katalonię, ponieważ ta odrodzi się w przyszłości. Założenia te legły u podstaw nurtu ideowopolitycznego - pujolizmu, który po zakończeniu dyktatury i przejęciu władzy w Katalonii przez Convergencia i Unio (CiU) mógł być swobodnie wdrażany, a tym samym na 23 lata pośrednio definiował relacje między Barceloną a Madrytem ${ }^{20}$. Istotną rolę w tym kontekście odgrywała resuscytacja języka katalońskiego i stopniowe nadawanie mu nadrzędnej pozycji oraz odbudowa i promocja katalońskiej historii i kultury, bo to one, zdaniem nacjonalistów i independentystów, stanowią o przetrwaniu i sile narodu katalońskiego. Celem nie była niepodległość, lecz prężnie prosperująca, konkurencyjna gospodarka oraz sukcesywne rozszerzanie kompetencji wspólnoty autonomicznej. Warto zaznaczyć, iż do końca pierwszej dekady XXI wieku politycy koalicji CiU w swoich programach nie wysunęli postulatów o charakterze stricte independentystycznym.

Do grona kaznodziejów independentyzmu należy zaliczyć także Artura Mas i Gavarró, lidera CiU. Porażki koalicji w wyborach regionalnych w 2003 i 2006 roku sprawiły, iż federacja stopniowo zaczęła przechodzić na stanowisko proniepodległościowe. Przykładem jest zainicjowanie akcji odnowienia ruchu katalonistycznego - Casa Gran del Catalanisme $e^{21}$. Już od wyborów w 2010 roku wyraźnie zaznaczał się rys independentystyczny ugrupowania, a jego egzemplifikacją był program wyborczy CiU z 2012 roku $^{22}$. A. Mas zadeklarował wówczas, iż „nadszedł czas, by nadać Katalonii strukturę państwową" ${ }^{23}$. Kolejni prezydenci Generalitat już otwarcie utożsamiali się z independentyzmem i realizowali jego założenia.

W kwestii liderów ruchu niepodległościowego w Katalonii niemałe znaczenie ma postrzeganie ich przez część społeczeństwa jako męczenników za słuszną sprawę. Początkowo independentyści często odwoływali się do ikony nowoczesnego katalonizmu - J. Pujola, który podczas reżimu frankistowskiego był represjonowany.

${ }_{18}$ Zob. M. Myśliwiec, Katalonia na drodze do niepodległości?, Bytom 2006, s. 42-44.

19 Por. J. Lores, Aproximació al pujolisme, „Taula de canvi”, wrzesień-październik 1979, nr 23-24.

${ }^{20}$ Por. M. Myśliwiec, Pozycja partii regionalnych w systemie politycznym wspótczesnej Hiszpanii, Katowice 2014, s. 213.

${ }^{21}$ Por. A. Barrio, Convergència i Unió, del nacionalismo moderado al secesionismo: cambio de posición de los partidos nacionalistas y sistema de gobierno multinivel, Working Papers, nr 330, Institut de Ciències Polítiques i Socials, Barcelona 2014, s. 11.

${ }_{22}$ Zob. J.-S. Mora, Katalonia na drodze do niepodlegtości, „Le Monde Diplomatique” 2013, nr 10/92.

${ }^{23}$ Por. President Mas: „Encara estem mes a prop de la plenitud nacional, res sera facil pero tot es possibile", 12.09.2012, http://www.govern.cat/pres_gov/AppJava/govern/grans-reptes/transicio-nacional/ notapremsa-161106.html?mode=static [dostęp: 12.05.2017]. 
Sytuacja uległa zmianie w wyniku afer korupcyjnych nagłośnionych w 2016 roku, w które zamieszani byli m.in. J. Pujol oraz A. Mas. Pierwsza dotyczyła tzw. sprawy Millet, czyli prania pieniędzy przez fundację Palau de la Musica, które następnie trafiały na konta $\mathrm{CiU}^{24}$. Druga afera, tzw. el caso Pretoria, związana była ze sprzedażą gruntów po zaniżonej wartości. Kolejna, tzw. afera 3\%, obnażyła współpracę polityków regionalnych z biznesmenami katalońskimi, którzy wpłacali na konta partyjnych fundacji CatDem i Barcelona Forum wysokie datki, w zamian za wygraną w fikcyjnych przetargach i publicznych kontraktach ${ }^{25}$. Jednak czarę goryczy przelało odkrycie w rajach podatkowych ukrytych majątków J. Pujola i jego rodziny.

Wspomniane afery znacznie nadwyrężyły również pozycję A. Masa, który z początkiem drugiej dekady XXI wieku stał się twarzą ruchu independentystycznego jako prezydent Generalitat. Przyczyniło się do tego m.in. forsowanie przez niego proniepodległościowych aktów prawnych, takich jak na przykład Deklaracja suwerenności, oraz promowanie wszelkiego rodzaju mobilizacji społecznej, ukierunkowanej na secesję regionu ${ }^{26}$. Przepychanki prawne między parlamentem katalońskim a władzami centralnymi jeszcze bardziej zaogniły konflikt na linii centrum - peryferie. Ostatecznie planowane referendum niepodległościowe odbyło się w listopadzie 2014 roku i przyjęło postać konsultacji społecznych. W konsekwencji kwestia referendum podzieliła społeczeństwo katalońskie i pogłębiła antagonizmy katalońsko-hiszpańskie, A. Mas zaś został skazany przez sąd za „nieposłuszeństwo obywatelskie" na dwuletni zakaz sprawowania funkcji publicznych oraz ukarany grzywną. Wydarzenia te pozytywnie wpłynęły na budowanie independentystycznego przekazu, a sam A. Mas mógł odgrywać rolę męczennika za sprawę katalońską. Media transmitowały pochód Katalończyków wraz z A. Masem do budynku sądu, pokazując go jako gest solidarności. Dzięki temu widzowie mogli odnieść wrażenie, iż niemal wszyscy Katalończycy popierają idę niepodległości, tymczasem w marcu 2017 roku, kiedy zapadł wyrok, niewiele ponad 37\% Katalończyków opowiadało się za niepodległością regionu. Dla porównania w badaniu z lutego 2020 roku poparcie dla niepodległego państwa katalońskiego wynosiło $35,5 \%$. Biorąc pod uwagę przedstawione wyniki sondaży, a także fakt, iż przeprowadzał je ośrodek badań związany z Generalitat, nie można mówić o „większości” Katalończyków popierających niepodległość, ponieważ zwolennicy nie przekroczyli 50\% społeczeństwa w regionie, nawet w tak burzliwym okresie jak październik 2017 roku. Baròmetre d'Opinió Política najwyższy poziom poparcia dla idei independentystycznych od 2005 roku odnotował w listopadzie 2013 roku - wynosił on 48,5\% wśród osób badanych ${ }^{27}$.

${ }^{24}$ Por. T. Kubin, M. Lorencka, M. Myśliwiec, Wptyw kryzysu gospodarczego 2008 roku na działanie systemu politycznego. Analiza Przykładu Grecji, Hiszpanii i Włoch, Katowice 2017, s. 143-144.

${ }_{25}$ Por. M. Stasiński, Katalonia trzęsie korupcyjna ,, afera 3 procent”, „Gazeta Wyborcza”, 22.10.2015, http://wyborcza.pl/1,75399,19064363,katalonia-trzesie-korupcyjna-afera-3-procent.html [dostęp: 21.08. 2017].

${ }^{26}$ Zob. P. Hankus, Rok 2014 czasem katalońskiego referendum, „Dyplomacja i Bezpieczeństwo” 2014, nr 1(2), s. 215-230.

${ }^{27}$ Baròmetre d'Opinió Política, http://ceo.gencat.cat/ca/barometre/detall/index.html?id=6508 [dostęp: 20.03.2020]. 
Podobną narrację independentyści starają się prowadzić o ofierze Carlesa Puigdemonta. Zgodnie z nią były prezydent Generalitat musiał udać się na emigrację w obawie przed osadzeniem w hiszpańskim więzieniu. Taką optykę podsycał wydany przez Sąd Najwyższy Hiszpanii europejski nakaz aresztowania ${ }^{28}$ oraz duża aktywność samego C. Puigdemonta w mediach społecznościowych, a także zaangażowanie w inicjatywy popularyzujące kwestię katalońską poza Hiszpanią. Oponenci independentystów, jak i duża część podmiotów bloku proniepodległościowego wskazują, iż brak zdecydowanych kroków co do ogłoszenia niepodległości przez C. Puigdemonta po referendum w 2017 roku, a następnie jego wyjazd wraz z najwyższymi rangą urzędnikami zostały odczytane przez wielu jako ucieczka, zdrada i pozostawienie za sobą w regionie „,chaosu i pożogi”'29.

Ponadto rolę męczenników za niepodległą Katalonię pełnią aktualnie: politycy i aktywiści bezpośrednio związani z organizacją wspomnianego referendum, skazani w październiku 2019 roku na długoletnie wyroki więzienia: od 9 do 13 lat. Wokół nich skupiają się zatem działania independentystów: manifestacje, strajki czy próby włączenia w rozwiązanie problemu instytucji unijnych, mające na celu ich uwolnienie. W powyższą strategię wpisuje się spór między władzami regionalnymi a rządem hiszpańskim oraz instytucjami Unii Europejskiej o uznanie ważności wyboru na deputowanych do Parlamentu Europejskiego C. Puigdemonta oraz Antonia Comína. Wybory odbyły się 26 maja 2019 roku, natomiast dopiero w grudniu 2019 roku Trybunał Sprawiedliwości Unii Europejskiej zdecydował o odwieszeniu immunitetów obu Katalończyków oraz Oriola Junquerasa. W styczniu 2020 roku Parlament Europejski uznał wszystkich wymienionych za legalnie wybranych deputowanych ${ }^{30}$. Jednak kilka dni później przewodniczący Parlamentu Europejskiego wygasił mandat O. Junquerasa $z$ uwagi na fakt, iż po wyborach do instytucji unijnej został on skazany prawomocnym wyrokiem.

W ramach ewangelizacji proniepodległościowej utwierdzanie Katalończyków w przekonaniu, że independentyzm stanowi jedyną drogę do wypełnienia mesjańskiej misji - utworzenia własnego państwa - wydaje się możliwe dzięki permanentnemu przekazywaniu swoistej ,dobrej nowiny”. Independentyzm (podobnie jak religie) przez część zwolenników interpretowany jest jako specyficzna rewindykacja, usprawiedliwienie dla uciskanej mniejszości ${ }^{31}$. Inny mechanizm stanowi budowanie dychotomii i podkreślanie różnic między Katalonią a pozostałymi regionami Hiszpanii na zasadzie: „my” - „obcy”, kreując tym samym wspólnego wroga - Hiszpanię. Pozwala to na zacieśnianie więzi emocjonalnych między członkami wspólnoty,

28 Por. S. Jones, Violent clashes over Catalan separatist leaders' prison terms, „The Guardian”, 14.10.2019, https:/www.theguardian.com/world/2019/oct/14/catalan-separatist-leaders-given-lengthy-prison-sentences [dostęp: 20.02.2020].

29 Por. B. Wesel, Komentarz: Niechwalebna ucieczka Puigdemonta, http://www.dw.com/pl/komentarz-niechwalebna-ucieczka-puigdemonta/a-41230494 [dostęp: 6.01.2017].

30 Por. C. Gallardo, Parliament to recognize jailed Catalan separatist as MEP next week, 06.01.2020, https://www.politico.eu/article/oriol-junqueras-carles-puigdemont-parliament-to-recognize-jailed-catalan-separatist-as-mep-next-week/ [dostęp: 3.03.2020].

31 Por. D. Gascon, El independentismo como religión, „E1 País”, 06.10.2018, https://elpais.com/elpais/2018/10/05/opinion/1538759473_533405.html [dostęp:11.06.2021]. 
pogłębianie poczucia jedności, ale także zwiększenie mobilizacji społecznej w obliczu zagrożenia płynącego spoza wspólnoty.

Podmiotów independentystycznych dokonujących ewangelizacji w tym nurcie jest wiele. Jednym z nich jest Assemblea Nacional Catalana (ANC), której statutowy cel stanowi utworzenie niepodległego państwa katalońskiego. Stowarzyszenie przygotowuje wydarzenia, manifestacje, akcje promocyjne. Wykorzystuje komunikatory internetowe, portale społecznościowe oraz własne kanały. ANC zaistniało w przestrzeni publicznej głównie za sprawą organizacji Marszu Wolności pod hasłem: Katalonia - nowe państwo w Europie we wrześniu 2012 roku, gromadząc na nim, według różnych danych, od 600 tys. do $1,5 \mathrm{mln}$ osób $^{32}$. Od tego czasu ANC zdominowało coroczną La Diadę, organizując manifestacje proniepodległościowe. Ponadto ANC uruchomiło cykl inicjatyw na rzecz referendum niepodległościowego w 2014 i 2017 roku, angażując w nie m.in. znane osobistości.

W zakresie swoistej ewangelizacji i katechizacji Katalończyków ANC podejmuje kooperacje z innymi podmiotami proniepodległościowymi. Tego typu partnerem jest Òminium Cultural, organizacja non-profit, która należy do najbardziej wpływowych grup nacisku na działania Generalitat. Za przełomowy moment jej aktywności można uznać organizację manifestacji Jesteśmy narodem. My decydujemy w 2010 roku $^{33}$, która była jednym z pierwszych impulsów świadczących o radykalizacji independentyzmu katalońskiego.

Podmiotem powstałym w 2011 roku w celu promowania prawa do decydowania przez Katalończyków Dret a Decidir de Catalunya jest Associació de Municipis per la Independència (AMI). Stowarzyszenie powołano w następstwie konsultacji społecznych w sprawie niepodległości w latach 2009-2011. Możliwości oddziaływania AMI na Katalończyków są bardzo duże, gdyż swoim zasięgiem obejmuje cztery prowincje: Barcelonę, Tarragonę, Gironę i Lleidę, zrzesza 790 municypiów, czyli ponad 85\% ich ogólnej liczby, 52 rady w katalońskich comarcales i diputaciones oraz inne organy samorządowe i organizacje dążące do utworzenia silnego, niepodległego regionu $^{34}$. Tym samym AMI reprezentuje blisko $60 \%$ Katalończyków.

Do współpracy na rzecz krzewienia independentyzmu katalońskiego włączają się także mniejsze podmioty, jak na przykład: Súmate ${ }^{35}$, Platforma ProSeleccions Esportives Catalanes ${ }^{36}$, Cercle Català de Negocis ${ }^{37}$. Stosunkowo nowym ruchem, który zaangażował się w walkę niepodległościową, jest Tsunami Democràic, organizator spektakularnych inicjatyw, na przykład blokady najważniejszych autostrad w Katalonii, lotniska El Prat czy manifestacji i oblężenia okolic stadionu Camp Nou podczas El Clásico ${ }^{38}$. Podmiot ma bardzo duży potencjał mobilizacyjny dzięki wykorzystaniu

32 Są to dane podawane odpowiednio przez: służby porządkowe i policję oraz organizatorów.

${ }_{33}$ Por. Óminium Cultural, https://www.omnium.cat/castellano [dostęp: 24.07.2017].

${ }_{34}$ Por. $A M I$, http://www.municipisindependencia.cat/ [dostęp: 29.02.2020].

${ }^{35}$ Organizacja promująca idę niepodległości Katalonii pośród społeczności hiszpańskojęzycznej.

${ }^{36}$ Stowarzyszenie popularyzujące sport kataloński.

${ }^{37}$ Stowarzyszenie katalońskich przedsiębiorców i biznesmenów opowiadających się za niepodległością Katalonii oraz ochroną rodzimych firm.

${ }^{38}$ Mecz między Realem Madryt a FC Barceloną. 
nowych technologii, portali społecznościowych czy komunikatorów internetowych oraz współpracy z bliźniaczymi grupami poza Hiszpanią.

Ewangelizacja w duchu independentyzmu może być częściowo realizowana za pośrednictwem mediów, zwłaszcza tych o zasięgu regionalnym. Katalonia należy do prekursorów budowy własnego systemu medialnego i wyróżnia się dużą autonomią w stosunku do mediów hiszpańskojęzycznych. Hiszpański system medialny można sklasyfikować jako model spolaryzowanego pluralizmu ${ }^{39}$. Charakteryzuje się on głębokimi podziałami ideologicznymi, pluralizm opinii zaś staje się pluralizmem zewnętrznym, w związku z tym dochodzi do polaryzacji mediów zgodnie z przyjętym światopoglądem, jak również daną linią partyjną. W rzeczywistości oznacza to, iż stacja telewizyjna lub radiowa, tytuł prasowy czy też strony internetowe są przeznaczone dla konkretnych odbiorców, wyodrębnionych według podziałów społeczno-politycznych ${ }^{40}$. Co ważne, system medialny w Hiszpanii ze względu na kryterium własności kształtuje się na poziomie ogólnokrajowym i regionalnym bardzo podobnie, tzn. na obu poziomach mamy do czynienia jednocześnie z mediami publicznymi i prywatnymi, a w ich obrębie znajdują się: radiofonia, telewizja, prasa, portale internetowe o charakterze tematycznym i ogólnoinformacyjnym. Nieodzowną cechą hiszpańskich systemów medialnych jest także silne zespolenie i przenikanie się związanych z nimi elit z decydentami politycznymi.

Wspomniany paralelizm polityczny zyskuje w przypadku independentyzmu katalońskiego szczególne znaczenie, ponieważ rządzące $\mathrm{w}$ regionie ugrupowanie ma potencjalnie największy wpływ na kształtowanie polityki medialnej. Ponadto duża część katalońskich mass mediów pełni funkcje społeczno-polityczne, tj. są wykorzystywane do przekazu treści płynących ze strony polityków do danych grup społecznych. Mogło to powodować, że independentyści, a wcześniej nacjonaliści będący u władzy próbowali wykorzystać środki masowego przekazu na przykład do ewangelizacji (a nawet indoktrynacji) w duchu idei nacjonalistycznych i niepodległościowych. Tendencja taka dała się zauważyć choćby w TV3, a także jej sprofilowanych kanałach, jak: Super3, 3/24, C33 oraz Esport $3^{41}$. Warto jednak zaznaczyć, że o ile w przeszłości władze regionalne miały duży wpływ na kształt przekazu i działanie mediów, o tyle współcześnie w Katalonii dominuje proces odpolitycznienia mediów publicznych, co potwierdzają sukcesywnie wprowadzane ustawy medialne. Zaawansowanie tych działań podkreśla Dagmara Głuszek-Szafraniec, wskazując jednocześnie, iż przechodzą one od postaci mediów tożsamościowych w stronę niezależnego profesjonalizmu ${ }^{42}$.

${ }^{39}$ Por. D.C. Hallin, P. Mancini, Systemy medialne. Trzy modele mediów i polityki w ujęciu porównawczym, Kraków 2007, s. 89.

${ }^{40}$ Por. D. Głuszek-Szafraniec, Polityka medialna w Katalonii i Kraju Basków jako narzędzie rozwoju tożsamości regionalnych, „Pogranicze. Studia Społeczne” 2017, t. XXIX, s. 101.

${ }^{41}$ Por. D. Głuszek-Szafraniec, Krajobraz mediów katalońskich. Szkic medioznawczy, [w:] ¿Adónde vas, España? Przemiany polityczne w Hiszpanii i Ameryce Łacińskiej na przełomie XX i XXI wieku, S. Dudra, Ł. Młyńczyk, R. Michalak (red.), Sieniawa Żarska 2017, s. 186.

${ }^{42}$ Eadem, Publiczni nadawcy w regionach autonomicznych Hiszpanii. Między misją a polityka, Katowice 2020, s. 310-336. 
Do najbardziej opiniotwórczej prasy codziennej, która może służyć independentystom za platformę do ewangelizacji, należy zaliczyć: „El Punt Avui” i „Ara”, gazety codzienne o profilu zdecydowanie sprzyjającym tendencjom katalonistycznym i niepodległościowym, a jednocześnie najbardziej dotowane przez rząd ${ }^{43}$. Tezę tę wzmacnia fakt, iż prasa regionalna cieszy się większą popularnością niż dzienniki ogólnokrajowe, w tym „El País”, „El Mundo” czy „ABC”44.

Carlos Antonio Ballesteros Herencia na podstawie teorii framingu (teoria ramowania $)^{45}$, która zakłada selekcję pewnych aspektów rzeczywistości i podkreślenie ich widoczności dla propagowania przyjętych poglądów, idei, ocen, co oznacza także prezentowanie faktów z określonej perspektywy, wskazuje, że prasa określana w jego badaniu jako hiszpańska, czyli: „El País”, „El Mundo”, „ABC”, oraz prasa katalońska, tj. „La Vanguardia”, „El Periódico”, „El Punt Avui”, różnie przedstawiały problem referendum niepodległościowego w regionie w 2014 roku. Tym samym objęły one kontrolę nad zawartością przekazu, dostarczając czytelnikowi wskazówek, jak interpretować rzeczywistość na podstawie prezentowanych przez poszczególne tytuły prasowe treści. Wskazane dzienniki uznały referendum (konsultacje) za główny temat informacji o dużym znaczeniu. Autor oszacował jego poziom ważności na 3,44 w czterostopniowej skali ${ }^{46}$. Gazety eksponowały referendum przez pryzmat konfliktu (zwłaszcza tytuły hiszpańskie określały je jako „wyzwanie” wobec demokracji ${ }^{47}$, aczkolwiek prasa ogólnokrajowa wyraźnie podkreślała kwestie łamania prawa, a także negatywnie odnosiła się do działań independentystów katalońskich oraz instytucji regionalnych. Ponadto chętnie dokonywała personalizacji konfliktu i obarczała winą za jego pojawienie się A. Masa. W pozytywnym świetle stawiała premiera M. Rajoya i instytucje centralne. Równolegle dzienniki katalońskie dobrze lub bardzo dobrze oceniały działanie władz i instytucji regionalnych, a negatywnie postrzegały działania centrum. Widoczne stało się zatem zastosowanie przez prasę kryterium geograficznego odpowiednio do poziomu sprawowania władzy, tj. popieranie własnych instytucji i stanowisk politycznych, z jednocześnie negatywną oceną działań oponentów. Potwierdza to następujący mechanizm: przed referendum przekaz prasy hiszpańskiej skupiał się głównie na działaniach decydentów katalońskich, kwalifikowanych jako sprzeczne z prawem; w tym samym czasie dzienniki katalońskie „La Vanguardia”, „El Periódico” i „El Punt Avui” tożsame posunięcia interpretowały jako legalne poczynania polityczne. Powyższa sytuacja mogła powodować dezinformację czytelników.

${ }^{43}$ Przykładowo poziom finansowania na rok 2017 prezentuje: Resolució PRE/1042/2017, de 10 de maig, de convocatòria per a la concessió de subvencions estructurals a publicacions periòdiques en suport paper en català o en aranès, corresponent a l'any 2017, DOGC Núm. 7371.

${ }^{44}$ Por. D. Głuszek-Szafraniec, System mediów w Hiszpanii. Różnice regionalne, „Zeszyty Prasoznawcze" 2019, t. 62, nr 4 (240), s. 162.

${ }^{45}$ Zob. P. Zielonka, Framing, czyli efekt sformulowania, „Decyzje” 2017, nr 27, s. 41-68.

${ }^{46}$ Por. C.A. Ballesteros Herencia, El desafio inadvertido. La consulta sobre la independencia de Cataluña desde el marco informativo del conflicto, „Anàlisi. Quaderns de Comunicació i Cultura” 2015, nr 53, s. 60 .

${ }^{47}$ Ibidem. 
W powyższym kontekście fundamentalne znaczenie zyskuje język kataloński, który stał się pośrednio instrumentem służącym realizacji independentystycznych celów. Na terenie Hiszpanii to właśnie w Katalonii istnieje najwięcej znaczących mediów $^{48}$ prezentujących treści we własnym języku. Jego uprzywilejowana pozycja ujawnia się m.in. we wspólnotowym systemie finansowania mediów, gdzie jest on podstawowym kryterium przydzielania subwencji. Również przyznanie koncesji nadawcom naziemnym, kablowym oraz radiowym uzależnia się od udziału w ramówce programowej produkcji czy audycji w języku katalońskim. Podobny wymóg dotyczy prasy i mediów internetowych. Regionalne władze przykładają bardzo dużą wagę do projektów realizowanych w sieci. Cel tych działań stanowi rewitalizacja rodzimego języka w sferze publicznej, ale także w codziennej komunikacji, oraz promocja katalońskiej kultury, w tym kultury popularnej.

Jak zauważa D. Głuszek-Szafraniec, nie bez znaczenia pozostaje pośrednia forma subwencji poprzez zamieszczanie ogłoszeń administracji publicznej, która w dużej mierze ma charakter uznaniowy. Sam podział środków, które przyznawane są zarówno podmiotom publicznym, jak i komercyjnym mediom prywatnym, publikującym lub emitującym w języku katalońskim, określany jest przez część polityków i publicystów hiszpańskich jako mechanizm tworzenia stronniczych mediów w regionie ${ }^{49}$. Od takich zarzutów odcinały się władze katalońskie, zwracając uwagę na przyznawanie środków finansowych na podstawie wyników konkursów, gdzie aplikujące podmioty muszą spełniać restrykcyjne kryteria ${ }^{50}$, które są szczegółowo określone.

Język kataloński jest nierozerwalnie związany z aspiracjami narodowymi znaczącej części mieszkańców regionu ${ }^{51}$. Aspekt językowy ma również znaczenie strategiczne ze względu na rozległy obszar domeny językowej. Współzależność języka katalońskiego ze stosunkiem Katalończyków do niepodległości badał m.in. Thomas J. Miley. Wykazał on, że wśród mieszkańców Katalonii utożsamiających się z językiem katalońskim ponad połowa opowiadała się za secesją regionu ${ }^{52}$. Wobec tego warto zadać sobie pytanie: które działania katalonistów i independentystów są ukierunkowane wyłącznie na podniesienie rangi rodzimego języka, a które z nich należałoby umiejscowić w konkretnej rzeczywistości społeczno-politycznej i odczytywać jako wyraz dążeń secesjonistycznych?

Niewątpliwie popularyzacja języka katalońskiego może stanowić zabieg polityczny ${ }^{53}$, ukierunkowany na systematyczne powiększanie wspólnoty katalońskiej. Stąd też wynika duży nacisk na posługiwanie się w systemie edukacji el català, włącznie

${ }^{48}$ Por. D. Głuszek-Szafraniec, Krajobraz mediów katalońskich..., op. cit., s. 179.

${ }^{49}$ Eadem, Krajobraz mediów katalońskich ..., op. cit., s. 186-187.

${ }_{50}$ Zob. Valoració del posicionament de la cultura catalana. Visió i marc general del diagnòstic per sectors culturals, https://cultura.gencat.cat/web/.content/sid/ articles_diversos_2012/documents/ presentacio_pla_estrategic_sectors_unificada_final.pdf [dostęp: 26.03.2020].

${ }_{51}$ Por. M. Skobrtal, Separatyzm językowy, „Refleksje. Pismo naukowe studentów i doktorantów WNPiD UAM", wiosna-lato 2010, nr 1, s. 139.

${ }_{52}$ Zob. J. Miley, T.J. Garvía, Linguistic Immersion' and Political Conflict in Contemporary Catalonia, „European Journal of Language Policy” 2013, vol. 5, nr 1, s. 5-40.

${ }_{53}$ Por. Democratic Policies for Language Revitalisation: the Case of Catalan, M. Strubell, E. Boix-Fuster (red.), London 2011, s. 224-244. 
z nauką języka dla imigrantów. Już od połowy XIX wieku Katalończycy walczyli o powrót języka katalońskiego do edukacji, co potwierdzają słowa A. Rovira i Virgili: „Nauczanie we własnym języku jest rzeczywiście prawem narodu, o ogromnym znaczeniu”, dlatego jego zdaniem konieczne było stworzenie „,fortecy nauczania narodowego", która miała stać się zaporą dla wpływów obcych języków ${ }^{54}$.

Zaangażowanie Generalitat w zakresie finansowym, organizacyjnym i merytorycznym skutkowało podniesieniem rangi języka katalońskiego oraz jego upowszechnieniem w różnych sferach życia Katalończyków. Sprawiło to, że jego znajomość stała się czynnikiem determinującym awans społeczny, ekonomiczny oraz wspomagającym asymilację ${ }^{55}$. Jednocześnie nierzadkie są zjawiska świadczące o dyskryminacji języka hiszpańskiego czy arańskiego, pomimo iż w Hiszpanii przyjęto zasady bilingwizmu. Przykładem tego zjawiska jest niechęć independentystów wobec imigrantów (z państw hiszpańskojęzycznych) posługujących się wyłącznie językiem hiszpańskim.

Warto podkreślić, że nauczanie w szkołach i na uniwersytetach jest również dogodną platformą dla głoszenia założeń independentyzmu, m.in. za pomocą określonych treści programowych. Znaczenie edukacji w języku katalońskim oraz możliwości oddziaływania na proces kształcenia przez decydentów regionalnych widać także na przykładzie zmian wprowadzonych do przepisów nowego statutu w 2006 roku: władze regionu miały uzyskać wyłączne kompetencje w zakresie edukacji, mieszkańcy zaś obligatoryjnie posługiwać się językiem katalońskim. Na mocy wspomnianego orzeczenia trybunału wiele artykułów zostało uznanych za niekonstytucyjne lub wymagało reinterpretacji, w tym te dotyczące języka katalońskiego, któremu odebrano pozycję dominującą względem języka hiszpańskiego w edukacji i administracji ${ }^{56}$. Pomimo tego znaczenie el català dla samych Katalończyków oraz możliwość jego oddziaływania na relacje społeczno-polityczne wydają się nie do przecenienia.

\section{Konkluzje}

Przeprowadzona analiza wskazuje, iż współczesny independentyzm, który ma swoje korzenie w nacjonalizmie katalońskim, jest zjawiskiem zróżnicowanym wewnętrznie, o różnych prędkościach i motywacjach. Jako myśl polityczna formował się od pierwszych dekad XX wieku, a w kształcie ruchu społeczno-politycznego ujawnił się blisko wiek później. Od 2010 roku wyraźnie zauważalna jest jego radykalizacja i wzmożona działalność. W związku z tym konieczne stało się poszukiwanie narzędzi i mechanizmów wspierających jego efektywność. Wyjątkowo użyteczna w tym zakresie okazała się sfera sacrum. Dzięki wykorzystaniu atrybutów tradycyjnych

\footnotetext{
${ }^{54}$ Por. A. Rovira i Virgili, Nacionalisme i Federalisme, Barcelona 1982, s. 214.

${ }_{55}$ Por. A. Grzechynka, Doktryna katalonizmu a wspótczesna polityka językowa Katalonii wobec imigrantów, Kraków 2017, s. 259-268.

${ }^{56}$ Por. A. Idzik, Co dalej z Katalonią? Rozważania nad przyszłościa katalanizmu po wyborach lokalnych z 28 listopada 2010 roku, „Sprawy Międzynarodowe” 2011, nr 1 (LXIV), s. 104.
} 
religii jest w stanie przystosować się lepiej do wymogów zmieniającej się rzeczywistości. Zapożyczone elementy, takie jak na przykład narzucony kult, wizja raju, charakterystyczna kosmowizja i kanon wartości, obraz narodu wybranego podbudowany martyrologią narodową i mitologizacją historii czy ewangelizacja sprawiają, że zyskał on postać specyficznej religii, przypominającej religię polityczną. Szczególnie użyteczna w tym kontekście jest permanentna, intensywna ewangelizacja i katechizacja, która nierzadko zyskuje charakter indoktrynacji. Dzięki niej od wieków możliwie stało się podtrzymywanie założeń katalonizmu, a w ostatnich dekadach także independentyzmu.

W procesie ewangelizacji istotną rolę odgrywają kaznodzieje i męczennicy, najczęściej w osobach liderów politycznych, podmioty independentystyczne, zwłaszcza organizacje posiadające dużą liczbę członków i zwolenników. Ważnym ogniwem we wspomnianym nauczaniu misyjnym są mass media oraz proces edukacji, ze szczególnym uwzględnieniem odpowiednich treści programowych. Klamrą spajającą działalność wszystkich wymienionych jest wykorzystanie języka katalońskiego i głoszenie dobrej nowiny.

Analiza mechanizmów i narzędzi (podmiotów), jakimi dysponuje independentyzm, pozwala wysunąć ogólny wniosek, iż związane są one z różnymi płaszczyznami życia mieszkańców regionu. Ponadto niektóre z nich, na przykład edukacja czy polityka medialna, mają charakter systemowy, inne natomiast są reakcją ad hoc jednostek i organizacji proniepodległościowych lub stanowią zorganizowaną przez podmioty pozarządowe odpowiedź na aktualne problemy independentystów lub interakcje z rządem centralnym.

Poszerzanie sfery wpływów i konsolidacja nacjonalizmu są realne dzięki jego ewolucji od postaci kulturowej, poprzez polityczną, aż do włączenia podmiotów i instytucji. Można zauważyć w tym zakresie co najmniej jeden wspólny element, tzn. zarówno katalonizm, jak i independentyzm - zwłaszcza na ostatnim etapie - wymagają szerokiego rozpowszechniania. Tylko takie działania mogą zapewnić żywotność ich założeniom i efektywność narracji proniepodległościowej, dlatego prowadzenie ewangelizacji jest tak istotne.

\section{Bibliografia}

Alonso S., Challenging the State: Devolution and the Battle for Partisan Credibility, Oxford 2012. Ballesteros Herencia C.A., El desafio inadvertido. La consulta sobre la independencia de Cataluña desde el marco informativo del conflicto, „Anàlisi. Quaderns de Comunicació i Cultura” 2015, nr 53, s. 48-64.

Barraycoa J., Historias ocultadas del nacionalismo catalán, Madrid 2011.

Barrio A., Convergència i Unió, del nacionalismo moderado al secesionismo: cambio de posición de los partidos nacionalistas y sistema de gobierno multinivel, Working Papers, nr 330, Institut de Ciències Polítiques i Socials, Barcelona 2014.

Burgoński P., Modele relacji między religia i polityka, [w:] Religia i polityka. Zarys problematyki, P. Burgoński, M. Gierycz (red.), Warszawa 2014, s. 216-239.

Crexell i Playà J., El Complot de Garraf, Montserrat 1988. 
Cucurull F., Panoràmica del nacionalisme català: Del 1914 al 1931, París 1975.

Democratic Policies for Language Revitalisation: the Case of Catalan, M. Strubell, E. Boix-Fuster (red.), London 2011, s. 224-244.

Dobrowolski P., Separatyzm ślaski - historia i współczesność, [w:] Regionalizm a separatyzm historia i współczesność. Ślask na tle innych obszarów, M.W. Wanatowicz (red.), Katowice 1995, s. 89-103.

Domínguez I., El alma independentista de la Iglesia catalana, „El País”, 29.09.2017, https://elpais. com/politica/2017/09/28/actualidad/1506627882_121321.html [dostęp: 11.06.2021].

Gallardo C., Parliament to recognize jailed Catalan separatist as MEP next week, https://www. politico.eu/article/oriol-junqueras-carles-puigdemont-parliament-to-recognize-jailed-catalanseparatist-as-mep-next-week/ [dostęp: 3.03.2020].

Gascon D., El independentismo como religión, „El País”, 06.10.2018, https://elpais.com/elpais/2018/10/05/opinion/1538759473_533405.html [dostęp: 11.06.2021].

Baròmetre d'Opinió Política, http://ceo.gencat.cat/ca/barometre/detall/index.html?id=6508 [dostęp: 20.03.2020].

Głuszek-Szafraniec D., Krajobraz mediów katalońskich. Szkic medioznawczy, [w:] ¿Adónde vas, España? Przemiany polityczne w Hiszpanii i Ameryce Łacińskiej na przełomie XX i XXI wieku, S. Dudra, Ł. Młyńczyk, R. Michalak (red.), Sieniawa Żarska 2017.

Głuszek-Szafraniec D., Polityka medialna w Katalonii i Kraju Basków jako narzędzie rozwoju tożsamości regionalnych, „Pogranicze. Studia Społeczne” 2017, t. XXIX, s. 95-122.

Głuszek-Szafraniec D., Publiczni nadawcy w regionach autonomicznych Hiszpanii. Między misja a polityka, Katowice 2020.

Głuszek-Szafraniec D., System mediów w Hiszpanii. Różnice regionalne, „Zeszyty Prasoznawcze” 2019 , t. 62 , nr 4 (240), s. 153-169.

Głuszek-Szafraniec D., Wpływ autonomii na rozwój mediów katalońskich i baskijskich, [w:] Media mniejszości. Mniejszości w mediach, M. Adamik-Szysiak, E. Godlewska (red.), Lublin 2014, s. 233-249.

Grzechynka A., Doktryna katalonizmu a wspótczesna polityka językowa Katalonii wobec imigrantów, Kraków 2017.

Hallin D.C., Mancini P., Systemy medialne. Trzy modele mediów i polityki w ujęciu porównawczym, Kraków 2007, s. 89.

Hankus P., Rok 2014 czasem katalońskiego referendum, „Dyplomacja i Bezpieczeństwo” 2014, 1 (2), s. 215-230.

Husar-Poliszuk W., Katalończycy. Od budowy własnej tożsamości do independentyzmu w regionie, Poznań 2020.

Husar-Poliszuk W., Secler B., Ślusarczyk P.S., Znaczenie katolicyzmu dla ksztattowania się katalonizmu i independentyzmu w Katalonii, [w:] eidem, Polityka wyznaniowa. Konteksty innych polityk publicznych. Austria, Katalonia, Polska, Zielona Góra 2018, s. 81-106.

Husar-Poliszuk W., Znaczenie czynnika religijnego w konstruowaniu katalońskiej tożsamości narodowej, Zielona Góra 2017.

Idzik A., Co dalej z Katalonią? Rozważania nad przyszłościa katalonizmu po wyborach lokalnych z 28 listopada 2010 roku, „Sprawy Międzynarodowe” 2011, nr 1 (64), s. 104.

Jones S., Violent clashes over Catalan separatist leaders' prison terms, „The Guardian”, 14.10.2019,https://www.theguardian.com/world/2019/oct/14/catalan-separatist-leaders-givenlengthy-prison-sentences [dostęp: 20.02.2020].

Kubiaczyk F., Historia, pamięć i nacjonalizm po katalońsku, „Studia Europaea Gnesnensia” 2015, nr 12.

Kubin T., Lorencka M., Myśliwiec M., Wpływ kryzysu gospodarczego 2008 roku na działanie systemu politycznego. Analiza Przykładu Grecji, Hiszpanii i Włoch, Katowice 2017, s. 143-144.

Kulak E.K., Kształtowanie się poczucia tożsamości Katalończyków na podstawie piśmiennictwa okresu odrodzenia kulturalnego i narodowego (XIX w. - początek XX w.), Kraków 2016. 
Lores J., Aproximació al pujolisme, „Taula de canvi”, wrzesień-październik 1979, nr 23-24.

Miley J., Garvía T.J., Linguistic Immersion' and Political Conflict in Contemporary Catalonia, „European Journal of Language Policy” 2013, vol. 5, nr 1, s. 5-40

Moa P., Los nacionalismos vasco y catalán: En la Guerra Civil, el franquismo y la democracia, Madrid 2013.

Mora J.S., Katalonia na drodze do niepodległości, „Le Monde Diplomatique” 2013, nr 10/92, edycja polska.

Myśliwiec M., Katalonia na drodze do niepodległości?, Bytom 2006.

Myśliwiec M., Pozycja partii regionalnych w systemie politycznym współczesnej Hiszpanii, Katowice 2014.

Nowy rząd Katalonii zaprzysiężony, koniec bezpośredniego nadzoru Madrytu, https://www.pap.pl/ aktualnosci/news\%2C1437908\%2Cnowy-rzad-katalonii-zaprzysiezony-koniec-bezposredniego-nadzoru-madrytu.html [dostęp: 26.03.2020].

AMI, http://www.municipisindependencia.cat/ [dostęp: 29.02.2020].

Ominium Cultural, https://www.omnium.cat/castellano [dostęp: 24.07.2017].

President Mas: „Encara estem mes a prop de la plenitud nacional, res sera facil pero tot es possibile”, http://www.govern.cat/pres_gov/AppJava/govern/grans-reptes/transicio-nacional/ notapremsa-161106.html?mode=static [dostęp: 12.05.2017].

Pujol J., Tot compromis comporta risc, Barcelona 1997.

Resolució PRE/1042/2017, de 10 de maig, de convocatòria per a la concessió de subvencions estructurals a publicacions periòdiques en suport paper en català o en aranès, corresponent a l'any 2017, DOGC Núm. 7371.

Roglan J., 14 d'abril: la Catalunya republicana (1931-1939), Valls 2006.

Rovira i Virgili A., Nacionalisme i Federalisme, Barcelona 1982.

Stasiński M., Katalonią trzęsie korupcyjna ,, afera 3 procent”, „Gazeta Wyborcza”, http://wyborcza. pl/1,75399,19064363, katalonia-trzesie-korupcyjna-afera-3-procent.html [dostęp: 21.08.2017].

Ucelay Da Cal E., Los „malos de la película”: las Joventuts d'Esquerra Republicana - Estat Català y la problemática de un „fascismo catalán”, „Ayer” 2005, nr 59, s. 147-172.

Valoració del posicionament de la cultura catalana. Visió $i$ marc general del diagnòstic per sectors culturals, https://cultura.gencat.cat/web/.content/sid/articles_diversos_2012/documents/presentacio_pla_estrategic_sectors_unificada_final.pdf [dostęp: 26.03 .2020$]$.

Vilches J., El catalanismo como religión, „El Español”, https://www.elespanol.com/opinion/tribunas/20180911/catalanismo-religion/337086291_12.html [dostęp: 12.06.2021].

Wesel B., Komentarz: Niechwalebna ucieczka Puigdemonta, http://www.dw.com/pl/komentarzniechwalebna-ucieczka-puigdemonta/a-41230494 [dostęp: 6.01.2017].

William J., Youngs T., The Congregationalists. Student edition, London 1998.

Zielonka P., Framing, czyli efekt sformułowania, „Decyzje” 2017, nr 27, s. 41-68. 